\title{
Mutagenic Effectiveness and Efficiency of EMS and Sodium Azide in Mungbean [Vigna radiata (L.) Wilczek]
}

\author{
C. S. Mahto*, Sweta Suman, Niraj Kumar and Shreya Sen
}

Dept. of Plant Breeding and Genetics, Birsa Agricultural University, Ranchi, Jharkhand (834 006), India

\section{Corresponding Author}

C. S. Mahto

e-mail: csmahto@gmail.com

\author{
Article History \\ Article ID: 3 C0828 \\ Received in $01^{\text {st }}$ November, 2017 \\ Received in revised form $15^{\text {th }}$ July, 2018 \\ Accepted in final form $27^{\text {th }}$ August, 2018
}

\begin{abstract}
The present experiment assesses the relative effectiveness and efficiency of two widely used chemical mutagens on two well adapted varieties of Mungbean namely Pusa Vishal and SML-668 which was treated with 3 different doses each of EMS $(0.2,0.4$, and $0.6 \%)$ and Sodium azide $(0.06,0.08$, and $0.1 \%)$. The relative effectiveness and efficiency was assessed from the data on biological damage in $\mathrm{M}_{1}$ generation and frequency of chlorophyll mutants in $\mathrm{M}_{2}$ generation. The mutagenic effectiveness was inversely proportional to the increasing concentrations or doses of mutagens in Sodium azide. Low concentrations were found to be most effective and had promotary effect on plant height, pods per plant, 100 seed weight, seed yield per plant, branches per plant and pod length while both promotary and inhibitory effect were observed for seeds per pod, days to flowering and days to maturity. Sodium azide (SA) was found to be more effective mutagen to produce high frequency of chlorophyll mutations followed by EMS. It was also found that the lower concentrations of both mutagens were most effective in both the varieties. The decrease in effectiveness with increasing concentrations of mutagen could be attributed to the biological damage (like seedling injury, lethality, and sterility) which increased with increase in dose at faster rate than the mutations. Mutagenic efficiency is referred to the frequency of chlorophyll mutations in relation to $M_{1}$ damage. Both the mutagens viz. EMS and Sodium azide exhibited gradual decrease in mutagenic efficiency with the increasing concentration or doses with respect to seedling injury and lethality.
\end{abstract}

Keywords: Effectiveness, efficiency, EMS, Sodium azide (SA), induced mutations, Mungbean

\section{Introduction}

Mungbean [Vigna radiata (L.) Wilczek] being a self-pollinated crop the naturally existing genetic variability is not sufficient to achieve the desired improvement. Due to small size of flower, emasculation and pollination in Mungbean [Vigna radiata (L.) Wilczek] is very tedious and costly. Alternately, induced mutations with the application of mutagens are the best way to enlarge genetic variability in this species considerably within a short time. Mutation breeding has made significant contribution in increasing the production of different crops like rice, groundnut, castor, chickpea, pigeonpea, mungbean and urdbean in Indian subcontinent. Mutation is the source of variability in the existing varieties. For the development of better crop, mutation breeding is best method (Awan et al., 2004). The heritability of important traits like production, resistance to insect and pest, and quality can be analyzed through analysis of induced mutations (Fawad et al., 2015; Kanwal et al., 2015; Mumtaz et al., 2015; Ramzan et al., 2015; Naseer et al., 2015)

Mutations are the source of variability in the existing varieties and early maturing lines can be developed which are helpful in the summer season. For the development of better crops, mutation breeding is the best method (Awan et al., 2004).

The heritability of the important traits such as production, resistance against pest and diseases and quality can be analyzed through analysis of the induced mutation (Fawad et al., 2015; Kanwal et al., 2015; Mumtaz et al., 2015; Rizwan et al., 2015; Naseer et al., 2015; Naseem et al., 2015; Masood et al., 2015a,b).

A number of chemical and physical mutagens are widely employed to induce genetic variability in plants. Ethyl Methane Sulphonate (EMS) is a well known potent mutagen, widely employed in induction of genetic variability; it is an alkylating agent and induces high frequency of base pair substitutions. Sodium azide (SA) is another most widely used chemical mutagen in crop improvement, generally used as respiratory inhibitor. Yield contributing traits (viz., Days to flowering, Days to maturity, plant height, primary branches plant ${ }^{-1}$, pods plant $^{-1}$, seeds pod ${ }^{-1}, 100$ Seed weight and seed yield plant ${ }^{-1}$ etc.) are the metric traits which are quantitatively inherited 
and directly or indirectly contribute to increase in yield of crop plants. Their inheritance is controlled by multiple (poly) genes. The selection of quantitative traits is more difficult than qualitative traits since they are characterized by the presence of whole spectrum of phenotypes (Naseem et al., 2015; Masood et al., 2015a,b; Javed et al., 2016).

The present study of frequency, spectrum, effectiveness, efficiency and effective concentration of these mutagens in inducing genetic variability in mungbean so that they can be assessed for their suitability for selection of elite genotypes and use in breeding programmes aimed at genetic improvement of mungbean. The experimental plant material used in the present investigation are two well adapted diverse variety of mungbean [Vigna radiata (L.) Wilczek.]-Pusa vishal and SML-668.

\section{Materials and Methods}

The present experiment was conducted during 2016-17 at Birsa Agricultural University, Kanke, Ranchi. The experimental plant materials used in the present investigation were two well adapted and genetically divergent, varieties of Mungbean [Vigna radiata (L.) Wilczek] cultivars-Pusa vishal and SML 668. These two varieties are widely cultivated in this area of the country. Seeds presoaked in water for 6 hours, were treated with different concentrations of EMS $(0.2 \%, 0.4 \%$ and $0.6 \%)$ and Sodium azide $(0.06 \%, 0.08 \%$ and $0.1 \%)$ for 7 hours at room temperature. Seeds not treated with the mutagens served as control. Some of the mutagen treated seeds (20) were grown in Petri plates with moist filter papers. These were used for germination studies and elongation of seedlings after 8 days of germination. About 200 seeds of each treatment were sown in the experimental field, along with controls, as treatment population to raise $M_{1}$ generation during kharif season of 2016. The individual seeds of $M_{1}$ plant progenies were sown in the field to raise $M_{2}$ progeny in subsequent season. Uniform cultivation methods and agricultural practices were followed raise all $M_{1}$ and $M_{2}$ generations.

\section{Results and Discussion}

\subsection{Mutagenic effectiveness}

Effectiveness and efficiency of mutagens are quite important, as far as the plant breeding is concerned. Mutagenic effectiveness is a measure of the frequency of mutation induced by a unit dose of mutagen while mutagenic efficiency represents the proportion of mutation in relation to the associated undesirable biological effects, such as chromosomal aberration, lethality and sterility induced by mutagen in question (Konzak et al., 1965) opined that the mutagenic efficiency carries lot of theoretical and practical importance.

In the present investigation lower concentrations of EMS and Sodium azide showed higher effectiveness values. In other words the effectiveness of the mutagens decreased with increase in concentration of mutagens. The mutagen Sodium azide was found to be most effective than mutagen Ethyl methane sulphonate. It was also found that the lower concentrations of both mutagens were most effective in both the varieties (Table 1). Sharma et al. (2005) also reported higher mutagenic effectiveness at lower concentrations of EMS and Sodium azide in urdbean. The decrease in effectiveness with increasing concentrations of mutagen has been reported by several authors, Jaykumar et al. (2003), Sharma et al., (2006) in urdbean. Bashir et al. (2013) reported effectiveness decreases with increase in dose of Sodium Azide. Increasing

Table 1: Mutagenic effectiveness and efficiency of EMS and Sodium azide mutagens in mungbean cv. Pusavishal and SML 668

\begin{tabular}{|c|c|c|c|c|c|c|c|c|c|c|c|}
\hline \multirow{2}{*}{\multicolumn{2}{|c|}{$\begin{array}{l}\text { Mutagenic } \\
\text { Treatments }\end{array}$}} & \multicolumn{5}{|c|}{ Pusa vishal } & \multicolumn{5}{|c|}{ SML 668} \\
\hline & & $\begin{array}{l}\text { Total } \mathrm{M}_{2} \\
\text { popula- } \\
\text { tion }\end{array}$ & $\begin{array}{c}\text { Freq of } \\
\text { chlorophyll } \\
\text { mutation } \\
\text { (Msf) }\end{array}$ & $\begin{array}{c}\text { Lethal- } \\
\text { ity } \\
\%(\mathrm{~L})\end{array}$ & $\begin{array}{l}\text { Effec- } \\
\text { tiveness } \\
=(\mathrm{Msf} / \\
\text { t.c) }\end{array}$ & $\begin{array}{c}\text { Effi- } \\
\text { ciency } \\
=(\mathrm{Msf} / \mathrm{L})\end{array}$ & $\begin{array}{l}\text { Total } \mathrm{M}_{2} \\
\text { popula- } \\
\text { tion }\end{array}$ & $\begin{array}{c}\text { Freq of } \\
\text { chlorophyll } \\
\text { mutation } \\
\text { (Msf) }\end{array}$ & $\begin{array}{c}\text { Lethal- } \\
\text { ity } \\
\%(L)\end{array}$ & $\begin{array}{l}\text { Effec- } \\
\text { tiveness } \\
=(\mathrm{Msf} / \\
\text { t.c) }\end{array}$ & $\begin{array}{c}\text { Effi- } \\
\text { ciency } \\
=(\mathrm{Msf} / \mathrm{L})\end{array}$ \\
\hline \multicolumn{2}{|c|}{ Control } & 298 & 0.00 & 0.0 & - & - & 295 & 0.00 & 0.0 & - & - \\
\hline \multicolumn{2}{|c|}{$\begin{array}{l}\text { Buffer } \\
\text { soaked }\end{array}$} & 296 & 0.00 & 0.5 & 0.00 & 0.000 & 290 & 0.00 & 0.6 & 0.00 & 0.000 \\
\hline \multirow[t]{3}{*}{ EMS } & $0.20 \%$ & 1452 & 0.69 & 25.6 & 0.49 & 0.027 & 1427 & 0.63 & 26.3 & 0.45 & 0.024 \\
\hline & $0.40 \%$ & 1428 & 0.84 & 31.4 & 0.30 & 0.026 & 1376 & 0.80 & 28.6 & 0.29 & 0.028 \\
\hline & $0.60 \%$ & 1310 & 0.99 & 43.2 & 0.24 & 0.023 & 1310 & 0.84 & 46.6 & 0.20 & 0.018 \\
\hline \multicolumn{2}{|c|}{ Average } & 1396 & 0.84 & 33.40 & 0.34 & 0.030 & 1371 & 0.76 & 33.83 & 0.31 & 0.020 \\
\hline \multirow[t]{3}{*}{ SA } & $0.06 \%$ & 1332 & 0.83 & 17.9 & 1.97 & 0.046 & 1550 & 0.84 & 26.6 & 1.99 & 0.032 \\
\hline & $0.08 \%$ & 1145 & 0.96 & 34.2 & 1.72 & 0.028 & 1337 & 0.97 & 40.0 & 1.74 & 0.024 \\
\hline & $0.10 \%$ & 1004 & 1.20 & 57.7 & 1.71 & 0.021 & 992 & 1.11 & 55.1 & 1.58 & 0.020 \\
\hline \multicolumn{2}{|c|}{ Average } & 1160 & 0.99 & 36.60 & 1.80 & 0.030 & 1293 & 0.97 & 40.57 & 1.77 & 0.030 \\
\hline
\end{tabular}


trend in lethality percentage was observed with increasing dose of sodium Azide in case of dry as well as soaked treatments in mungbean.

\subsection{Mutagenic efficiency}

Mutagenic efficiency is the ratio of frequency of chlorophyll mutations induced in $\mathrm{M}_{2}$ generation to various biological damages (such as seedling injury and lethality) observed in $M_{1}$ generation. Both the mutagens exhibited gradual decrease in mutagenic efficiency with the increasing concentration or doses with respect to seedling injury and lethality. From the data on mutagenic efficiency values, it could be observed that the $0.06 \%$ sodium Azide in both the variety Pusa Vishal (0.046) and SML 669 (0.32) were the most efficient in regard to lethality. Comparing the efficiency of both the mutagens it was at par with the variety Pusa Vishal, whereas in SML 668 Sodium Azide (SA) was more efficient than EMS (Table 1 and 2).

According to Konzak et al. (1965), higher efficiency at lower concentration of a mutagenic agent is due to the biological damage ( like seedling injury, lethality and sterility) which increases with increase in dose at faster rate than the mutations. Kumar et al. (2017) reported the same in soyabean.
Sharma et al. (2005) in urdbean reported that the lower doses of mutagens were more efficient than the higher doses. Sodium Azide are proved to be the most potent in inducing viable mutants (Rao et al. 1984).The responses of both the chemical mutagens are influenced by number of biological, environmental and chemical factors. Khan and Tyagi (2017) in soyabean observed more chlorophyll mutants at 0.2\% EMS.

Bhosale et al. (2013) reported that seed germination and survival of plants at maturity decreased with increasing concentration/dose of the mutagens, while seedling injury, pollen sterility and lethality were found increased with increasing concentration/dose of the mutagens in the present variety of Urdbean.

All the mutagens exhibited gradual decrease in mutagenic efficiency with the increasing concentrations or doses with respect to lethality. On the whole, when the mean values for mutagenic efficiency are compared, the higher values for lethality were found at higher doses of both Sodium Azide (SA) and EMS respectively. Similar result was reported by Khan and Wani (2006); Jain et al. (2013).

Table 2: Effect of EMS and sodium azide on seed germination, plant survival, seedling length and injury in $\mathrm{M}_{1}$ generation in mungbean

\begin{tabular}{|c|c|c|c|c|c|c|c|c|c|}
\hline \multirow{2}{*}{\multicolumn{2}{|c|}{$\begin{array}{l}\text { Mutagenic } \\
\text { treatments }\end{array}$}} & \multicolumn{4}{|c|}{ Pusa vishal } & \multicolumn{4}{|c|}{ SML-668 } \\
\hline & & $\begin{array}{l}\text { Germina- } \\
\text { tion (\%) }\end{array}$ & $\begin{array}{c}\text { Plant } \\
\text { survival (\%) }\end{array}$ & $\begin{array}{c}\text { seedling } \\
\text { length }(\mathrm{cm})\end{array}$ & $\begin{array}{c}\% \\
\text { injury }\end{array}$ & $\begin{array}{c}\text { Germination } \\
(\%)\end{array}$ & $\begin{array}{c}\text { Plant } \\
\text { survival (\%) }\end{array}$ & $\begin{array}{c}\text { Seedling } \\
\text { length }(\mathrm{cm})\end{array}$ & $\begin{array}{c}\% \\
\text { injury }\end{array}$ \\
\hline \multicolumn{2}{|c|}{ Control } & 100.0 & 98.96 & 5.12 & 0.00 & 99.0 & 100.00 & 5.31 & 0.00 \\
\hline \multicolumn{2}{|c|}{ Buffer soaked } & 96.9 & 99.47 & 5.10 & 0.39 & 97.5 & 99.45 & 5.16 & 2.82 \\
\hline \multirow[t]{3}{*}{ EMS } & $0.20 \%$ & 82.0 & 74.39 & 4.53 & 11.52 & 76.0 & 73.68 & 4.35 & 18.08 \\
\hline & $0.40 \%$ & 70.0 & 68.57 & 4.26 & 16.80 & 66.5 & 71.43 & 3.78 & 28.81 \\
\hline & $0.60 \%$ & 66.0 & 56.82 & 3.94 & 23.05 & 58.0 & 53.45 & 3.75 & 29.38 \\
\hline \multicolumn{2}{|c|}{ Average } & 72.67 & 66.59 & 4.24 & 17.12 & 66.83 & 66.19 & 3.96 & 25.42 \\
\hline \multirow[t]{3}{*}{ SA } & $0.06 \%$ & 84.0 & 82.14 & 3.78 & 26.17 & 79.0 & 73.40 & 3.42 & 35.59 \\
\hline & $0.08 \%$ & 77.5 & 65.81 & 3.32 & 35.16 & 70.0 & 60.00 & 2.86 & 46.14 \\
\hline & $0.10 \%$ & 68.5 & 42.34 & 3.09 & 39.65 & 49.0 & 44.90 & 2.57 & 51.60 \\
\hline \multicolumn{2}{|c|}{ Average } & 76.67 & 63.43 & 3.40 & 33.66 & 66.00 & 59.43 & 2.95 & 44.44 \\
\hline
\end{tabular}

\section{Conclusion}

Mutagenic effectiveness and efficiency are two reliable parameters in plant breeding which are used to evaluate a mutagen. The mutagenic effectiveness was inversely proportional to the increasing concentrations or doses of mutagens in Sodium Azide. Low concentrations were found to be most effective. EMS was found to be most effective mutagen in mungbean as compared to sodium Azide (SA) (SA>EMS). The decrease in effectiveness with increasing concentrations attributed to the biological damage.

\section{References}

Awan, M.A., Conzak, C.F., Rutzen, Nilan, R.A., 2004. Mutagen effect of sodium azide in rice. Crop Science 20, 663-668.

Bashir, S., Wani, A.A., Nawchoo, I.A., 2013. Mutagenic sensitivity of Gamma rays, EMS and Sodium Azide in Trigonellafoenum-graecum L. Science Research Reporter 3(1), 20-26.

Bhosale, U.P., Hallale, B.V., Dubhashi, S.V., 2013. M generation studies in Urdbean (Vigna mungo (L.) Hepper). Advances in Applied Science Research 4(3), 95-97.

Fawad, A., Muhammad, A., Kanwal, N., Niazi, N.K., Ahmad, Q., 2015. Crop improvement through conventional and non-conventional breeding approaches for grain yield and quality traits. Life Science Journal 12(4), 38-50.

Jayakumar, S., Selvaraj, R., 2003. Mutagenic effectiveness and efficiency of gamma rays and ethyl methane sulphonate 
in sunflower (Helianthus annuus L.). Madras Agricultural Journal 90(7-9), 574-576.

Jain, U.K., Ramkrishna, K., Jain, S.K., 2013. Comparative mutagenic efficiency, effectiveness and induced polygenic variability in mothbean (Vigna acontifolia L.). Indian Journal of Genetics and Plant Breeding 73(1), 57-63.

Javed, I., Ahsan, M., Ahmad, H.M., Ahmad, Q., 2016. Role of mutation breeding to improve mungbean (Vigna radiata L. Wilczek.) yield: An Overview. Nature and science 14(1), 63-77.

Kumar, A., Verma, N., Srivastava, N., Chakraborty, M., Prasad, K., 2017. Effect of Gamma Rays on seed germination, plant survival and quantitative characters on two varieties of soyabean (Glycine max) in $\mathrm{M}_{1}$ generation. Bulletin of Environment, Pharmacology and Life Sciences 6(1), 136-142.

Khan, M.H., Tyagi, S.D., 2017. Chlorophyll and morphological mutation induction in soyabean (Glycine max (L.) Merrill) through modified single seed bulk method. Academia Journal of Agriculture Research 5(9), 218-223.

Khan, S., Wani, M.R., 2006. MMS and SA induced genetic variability for quantitative traits in mungbean. Indian Journal of Pulses Research 19(1), 50-52.

Konzak, C.F., Wagner, T., Foster, R.J., 1965. Efficient chemical mutagenesis, the use of induced mutations in Plant Breeding (Rep. FAO/IAEA Tech. Meeting Rome, 1964). Porgamon Press, 49-70.

Kanwal, N., Sadaqat, H.A., Ali, F., Ali, Q., Hibi, I., Niazi, N.K., 2015. Breeding progress for morphology \& genetic pattern in Helianthus annuus L.. Life Science Journal 12(5s), 49-56.

Masood, S.A., Ishad, A., Machcha, A., Zam, N., Anum, J., Ali, Q., Samadh, A., 2015. An overview of genetic improvement for drought tolerance in rice. Life Science Journal 12(3), 63-70.

Masood, S.A., Sohal, J., Machcha, A., Zam, N., Anum, J., Ali, Q., 2015. Genetic association of transcriptional factors to incorporate drought tolerance in rice: An Overview. Life Science Journal 12(3), 17-26.

Mumtaz, A., Sadaqat, H.A., Sadaqat, S.M., Arif, M., Sahzad, A., Imran, K., Aleem, M.U., Ali, Q., 2015. Gene action studies through diallel analysis in Brassica rapa for quality traits. Life Science Journal 12(11), 19-27.

Naseem, M.Z., Masood, S.A., Kanwal, N., Ali, A., Anum, J., Ali, Q., 2015. Study of genetic variability in Helianthus anus for seedling traits:An Overview. Life Science Journal 12(3), 109-114.

Naseer, S., Kashraf, M., Ahmad, M.H., Iqbal, M.S., Ali, A., 2015. Assessment of genetic variability in Basmati and non basmati cultivars of Oryza sativa. Life Science Journal 12(4), 14-19.

Rao, D.M., Reddy, T.P. Manohar, R.D., 1984. Induction of mutations in pigeonpea (Cajanus cajan L.). Mutation Breeding Newsletter 24, 8.

Ramzan, I., Sadaqat, H.A., Shah, M., Ali, Q., 2015. Correlation and path coefficient analysis of yield component in S3 progenies of Helianthus anus. Life Science Journal 12(4), 109-112.

Sharma, A.K., Singh, V.P., Singh, R.M., 2006. Efficiency and effectiveness of the gamma rays, EMS and their combinations in urdbean (Vigna mungo L.). Indian Journal Pulses Research 19 (1), 111-112.

Sharma, S.K., Sood, R., Pandey, D.P., 2005. Studies on mutagen sensitivity, effectiveness and efficiency in urdbean [Vigna mungo (L.) Hepper]. The Indian Journal of Genetics \& Plant Breeding 65(1), 20-22. 